\title{
Monocyte chemoattractant protein-1 involvement in the $\alpha$-tocopherol-induced reduction of atherosclerotic lesions in apolipoprotein E knockout mice
}

\author{
Maria C. G. Peluzio ${ }^{3}$, Emir Miguel $\mathrm{Jr}^{1}$, Thaís C. Drumond ${ }^{1}$, Giovana C. César ${ }^{1}$, \\ Helton C. Santiago', Mauro M. Teixeira', Enio C. Vieira1, Rosa M. E. Arantes ${ }^{2}$ and \\ Jacqueline I. Alvarez-Leite ${ }^{1 *}$ \\ ${ }^{1}$ Departamento de Bioquímica e Imunologia and \\ ${ }^{2}$ Departamento de Patologia Geral, ICB, Universidade Federal de Minas Gerais, Caixa Postal 486, 30 161-970, \\ Belo Horizonte-MG, Brazil \\ ${ }^{3}$ Departamento de Nutrição e Saúde, Universidade Federal de Viçosa, Av PH Rolls s/n. 36570-000, Brazil
}

(Received 12 April 2002 - Revised 31 January 2003 - Accepted 21 February 2003)

\begin{abstract}
We studied the effects of $\alpha$-tocopheryl acetate supplementation on the development of fatty streaks and its ability to modulate the expression of monocyte chemoattractant protein (MCP)-1 in aortic lesions of apoliprotein E knockout mice. For this purpose, 16week-old apolipoprotein E knockout mice received $\alpha$-tocopherol supplemention $(800 \mathrm{mg}) / \mathrm{kg}$ diet) for 6 weeks. After this time, total and lipoprotein cholesterol in the serum, hepatic tocopherol, aortic lesion area and MCP-1 (protein and mRNA) expression were analysed. Our present results showed that the dietary supplementation with $\alpha$-tocopherol did not reduce serum cholesterol nor change lipoprotein profile, but it reduced the area of the aortic lesion by $55 \%$. The reduction in the lesion size was correlated with the reduced expression of MCP-1 mRNA and protein, as detected by real-time quantitative polymerase chain reaction and immunohistochemistry respectively. In conclusion, the results obtained here are relevant to the study of atherosclerosis, as they correlate the effectiveness of vitamin $\mathrm{E}$ supplementation in inhibiting the plaque formation with diminished expression of MCP-1 at the aortic lesion.
\end{abstract}

Atherosclerosis: Apolipoprotein E knockout mice: $\alpha$-Tocopherol: Monocyte chemoattractant protein-1: Antioxidant

In 1991, a workshop of the National Heart, Lung and Blood Institute discussed the oxidative hypothesis and the use of antioxidants in the prevention and treatment of atherosclerosis (Steinberg, 1992). As antioxidant vitamins have few adverse effects, trials with large doses of these vitamins were designed. Despite a clear rationale for its use, vitamin E supplementation has still an uncertain role in vascular disease.

Several reports have demonstrated the effect of vitamin $\mathrm{E}$ as an antioxidant, protecting the polyunsaturated fatty acids of the cellular membrane (Wefers \& Sies, 1988). Its role in the prevention of oxidative damage extends to DNA, protein, carbohydrate and lipid (Wefers \& Sies, 1988; Packer, 1991; Sies et al. 1992). As well as its antioxidant action, $\alpha$-tocopherol (TOH) has precise cellular functions. Ricciarelli et al. (2002) recently reviewed the non-antioxidant role of this vitamin. They pointed out that, at the post-translational level, $\alpha$-tocopherol inhibits protein kinase $\mathrm{C}$ and 5-lipoxygenase and activates protein phosphatase $2 \mathrm{~A}$ and diacylglycerol kinase. Other genes (CD36, $\alpha$-thiamin pyrophosphate, $\alpha$-tropomyosin and collagenase) are affected by $\mathrm{TOH}$ at the transcriptional level. $\mathrm{TOH}$ also induces inhibition of cell proliferation, platelet aggregation and expression of adhesion molecule, such as vascular cell adhesion molecule- 1 and intercellular cell adhesion molecule-1, important components of formation and progression of atherosclerosis.

Besides the 'oxidative hypothesis' of atherosclerosis, the inflammatory hypothesis assumes that some pro-inflammatory molecules are involved in atherosclerosis. Circumstantial evidence supports a role for monocyte chemoattractant protein (MCP)-1 in early phases of atherosclerosis. This chemokine, chemotactic for monocytes and $\mathrm{T}$ lymphocytes, is a member of the $\beta$-chemokine subfamily secreted by various cell types present in the arterial wall, including endothelial cells, smooth muscle cells, fibroblasts and macrophages, in response to many physiologically relevant signals (Gu et al. 1998). Inducers of MCP-1 expression include minimally modified LDL and fluid shear. Increased expression of MCP-1 has been described in the arterial wall of hypercholesterolaemic rabbits (Libby et al. 1996; Gu et al. 1998) and human plaques (Nelken et al. 
1991; Takeya et al. 1993). Moreover, studies using MCP1-deficient mice have suggested a correlation between MCP-1 expression, monocyte infiltration and the development of atherosclerotic lesions (Aiello et al. 1999). In this regard, both LDL-specific and cell-specific antioxidant actions may lead to decreased adhesion molecule and MCP-1 expression. As a consequence of the latter effects, decreased foam cell deposition, protection of vascular endothelium function, and decreased atherogenesis would be expected (Parthasarathy et al. 1998).

Apolipoprotein (Apo) E-deficient mice develop lesions very similar to those observed in human subjects (Nakashima et al. 1994; Reddick et al. 1994) and may be used as a tool in the study of the effects of vitamin E. In the present work, we investigated the effects of TOH supplementation on the size of aortic atherosclerotic lesions in ApoE knockout mice, focusing on the presence and expression of MCP-1. Our present results demonstrated that dietary supplementation with $\mathrm{TOH}$ was efficient in reducing expression of $\mathrm{MCP}-1$, which correlated with smaller lesion area in aortas from the experimental group.

\section{Methods}

\section{Animals and diets}

Forty-three 16-week-old ApoE knockout mice, obtained from Jackson Laboratories, Bar Harbor, ME, USA and maintained at the animal facilities of the Laboratory of Nutrition and Gnotobiology (Universidade Federal de Minas Gerais, Brazil), were used. Ten C57BL/6, mice fed chow diet were used as a wild-type control (CT) group for MCP-1 analyses. The animals were maintained in collective cages (maximum five animals per cage) in an appropriate room with controlled temperature and with a $12 \mathrm{~h}$ light-dark cycle. The animals had free access to water and food. The experimental protocol was accepted by the Animal Care Committee of the Instituto de Ciências Biológicas, Universidade Federal de Minas Gerais. The CT diet was based on the AIN-93G diet (Reeves et al. 1993) and was composed of ( $/ \mathrm{kg})$ : starch 610 , casein 200 , cellulose 50 , soyabean oil 70 , vitamin E-free vitamin mixture 10 , mineral mixture 50, choline 10. Acetate $\alpha$-tocopheryl (Sigma Chemical Co., St Louis, MO, USA) was added to the control $(40 \mathrm{mg} / \mathrm{kg}$ diet $)$ and supplemented group $(800 \mathrm{mg} / \mathrm{kg}$ diet $)$. Diets were kept in a dark room at $4^{\circ} \mathrm{C}$.

\section{Experimental protocol}

Before starting the experimental diet at 16 weeks of age, eleven animals were killed for the evaluation of the presence of lesions at the aortic root. The remaining animals were then divided into CT $(n$ 15) and TOH ( $n$ 17) groups and fed on the $\mathrm{CT}$ or $\mathrm{TOH}$-supplemented diet respectively for 6 weeks. Food intake and body weight were measured weekly. The experiment was continued until mice reached 22 weeks of age, when the animals were killed under anaesthesia. Blood was drawn from the axillary region and serum was separated by centrifugation at $2500 \mathrm{rpm}$ for $15 \mathrm{~min}$. Samples of serum and liver were gassed with
$\mathrm{N}_{2}$ (to eliminate $\mathrm{O}_{2}$ ) and frozen at $-20^{\circ} \mathrm{C}$ for the determination of total cholesterol and vitamin $\mathrm{E}$.

Serum lipoproteins were separated on fast protein liquid chromatography, as described by Fazio et al. (1997). Forty fractions of $500 \mu \mathrm{g}$ each were collected. A sample of $100 \mu \mathrm{l}$ was used for cholesterol determination by the enzymatic method adapted for a ninety-six-well microplate.

Hepatic lipids were extracted by the technique of Folch et al. (1957). Total cholesterol in serum and in the lipid extract of liver were determined by cholesterol oxidase enzymatic method (Allain et al. 1974) using a commercial kit (Katal, Belo Horizonte, Brazil).

The extraction and the determination of $\mathrm{TOH}$ in serum and liver were carried out according to the technique of Ueda \& Igarashi (1990).

Histological analysis. The heart and proximal section of the aorta were removed from animals and cleaned of adventitious tissue. The top half of the hearts was obtained under stereoscopic observation and fixed by immersion in paraformaldehyde $(40 \mathrm{ml} / \mathrm{l})$ in $0.1 \mathrm{M}-\mathrm{PBS}$ at room temperature. Specimens were routinely processed for paraffin embedding. The entire specimen was analysed (250 sections per mouse). The aortic root area was identified by the proximal presence of aortic valve leaflets. Every consecutive $5 \mu \mathrm{m}$ thick section throughout the aortic root area (300 $\mu \mathrm{m}$, sixty sections per mouse) was taken for analysis and stained with haematoxylin and eosin, according to Paigen et al. (1987). Of every five sections, one was kept for morphometrical analyses using a computerized image analyser (KS 300 program; Karl Zeiss, Berlin, Germany) attached to a micro-camera and microscope. The total lesion area of each animal represents the sum of lesion areas obtained from the ten sections analysed.

A second strategy for the quantification of atherosclerotic lesions was performed at the same anatomical level for both groups (sampled lesion area), measuring one selected section $180-200 \mu \mathrm{m}$ distal to the beginning of the aortic valve. This method has already been used by other authors to measure and compare aortic atherosclerotic lesions (Tangirala et al. 1995; Boisvert et al. 1999). The measurements of the three largest lesions of each mouse were used to give the average of the group. Morphometrical analyses were performed using the average of three repeated measurements of the lesions from each animal.

Immunohistochemistry. Tissue sections were deparaffinized with xylene and dehydrated with graded ethanol. Serial $5 \mu \mathrm{m}$ sections, obtained in representative areas and previously stained by haematoxylin and eosin, were chosen. Endogenous peroxidase activity was quenched by incubating the sections in $\mathrm{H}_{2} \mathrm{O}_{2}(300 \mathrm{ml} / \mathrm{l})$ for $30 \mathrm{~min}$ at room temperature. After washing, sections were blocked with goat serum $(50 \mathrm{ml} / \mathrm{l} \mathrm{PBS})$ for $30 \mathrm{~min}$. Anti-MCP-1 (rabbit anti-mouse sera, a kind gift from Dr N. W. Lukacs, University of Michigan) (5 ml/l PBS) was applied to the sections and incubated for $18 \mathrm{~h}$ at $4^{\circ} \mathrm{C}$ in a humidified chamber. The sections were washed, incubated with prediluted biotinylated secondary antibody (CA93013; Dako Corporation, Carpinteria, CA, USA) for $1 \mathrm{~h}$ and then washed again. The sections were incubated for $30 \mathrm{~min}$ with a peroxidase-labelled avidin-biotin complex (CA93013; Dako Corporation), washed, colour developed 
with diaminobenzidine and counterstained in haematoxylin. The percentage of MCP-1 positive cells was calculated by counting the total and MCP-1 positive inflammatory cells observed in ten different slides per mouse (five $\times 40$ fields per slide) and five mice per group. The average percentage per animal was used to perform the statistical analyses.

\section{Measurement of monocyte chemoattractant protein-1 expression by real-time quantitative polymerase chain reaction}

Fresh tissue samples were prepared using TRIzol reagent (GIBCO BRL, Rockville, MD, USA). Total RNA was extracted from a region of aorta stretching from the aortic arch until the kidney artery (CT $n 7$, TOH $n 9$, wild-type $n 3$ ) and cDNA prepared by reverse transcription. Briefly, RNA was measured spectrophotometrically and $1 \mu \mathrm{g}$ RNA was reverse transcribed using $25 \mathrm{U}$ M-MLV Reverse Transcriptase (Promega Corp., Madison, WI, USA) in $12.5 \mu \mathrm{l}$ reaction mixture containing $250 \mu \mathrm{M}$-dNTP (Promega Corp.), $50 \mathrm{~mm}$-Tris- $\mathrm{HCl}$ ( $\mathrm{pH} 8 \cdot 3$ ), $75 \mathrm{~mm}-\mathrm{KCl}, 3 \mathrm{~mm}-\mathrm{MgCl}_{2}$, $10 \mathrm{~mm}$-1,4-dithiothreitol, $10 \mathrm{U}$ RNAsin (GIBCO BRL), 7.5 $\mu \mathrm{M}$-oligo $\mathrm{dT}_{15}$ (GIBCO BRL). The mixtures were incubated for $5 \mathrm{~min}$ at $95^{\circ} \mathrm{C}, 5 \mathrm{~min}$ at $4^{\circ} \mathrm{C}$ and $5 \mathrm{~min}$ at $25^{\circ} \mathrm{C}$; at this step $25 \mathrm{U}$ reverse transcriptase was added to each sample and the reaction mixture was incubated for $60 \mathrm{~min}$ at $37^{\circ} \mathrm{C}$. The temperature was then elevated to $95^{\circ} \mathrm{C}$ for $5 \mathrm{~min}$ and cooled again at $4^{\circ} \mathrm{C}$ for $5 \mathrm{~min}$. The cDNA products were diluted up to $300 \mu \mathrm{l}$ with sterile bi-distilled water.

Real-time reverse transcription-polymerase chain reactions (PCR) were performed in the ABI-Prism 7900HT Sequence detection system (Perkin Elmer/Applied Biosystems, Foster City, CA, USA). Reaction conditions were programmed using the software SDS 2.0 on Windows NT 4.0 (Applied Biosystems, Foster City, CA, USA), linked directly to the sequence detector.

PCR amplifications were carried out as previously described (Overbergh et al. 1998). Briefly, the reactions were performed in a total volume of $25 \mu \mathrm{l}$ containing $2.5 \mu \mathrm{l}$ sample cDNA, $50 \mathrm{~mm}-\mathrm{KCl}, 10 \mathrm{~mm}-\mathrm{Tris}-\mathrm{HCl}(\mathrm{pH}$ 8.3), $10 \mathrm{~mm}$-EDTA, $60 \mathrm{~nm}$-passive reference $1,200 \mathrm{nmol}$ each primer/l, $500 \mu \mathrm{M}$-dATP, $500 \mu \mathrm{M}$-2'-deoxycytidine $5^{\prime}$-triphosphate, $500 \mu \mathrm{M}$-dGTP, $1000 \mu \mathrm{M}-2^{\prime}$-deoxyuridine 5 -triphosphate, $3.5 \mathrm{~mm}-\mathrm{MgCl}_{2}, \quad 0.5 \mathrm{U}$ AmpliTaqGold and $0.25 \mathrm{U}$ AmpErase Uracil N-Glycosylase (Perkin Elmer/Applied Biosystems). Each reaction contained $100 \mathrm{~nm}$ corresponding detection probe. PCR amplification of each sample was performed in triplicate wells, using the following conditions: $2 \mathrm{~min}$ at $50^{\circ} \mathrm{C}$ and $10 \mathrm{~min}$ at $95^{\circ} \mathrm{C}$, followed by a total of forty-five two-temperature cycles $\left(15 \mathrm{~s}\right.$ at $95^{\circ} \mathrm{C}$ and $60 \mathrm{~s}$ at $\left.60^{\circ} \mathrm{C}\right)$.

Primers and fluorogenic probes (purchased from Applied Biosystems) for the target genes are listed below and have been described previously (Giulietti et al. 2001): GAPDH forward TCACCACCATGGAGAAGGC, reverse GCTAAGCAGTTGGTGGTGCA, TaqMan Probe ATGCCCCATGTTTGTGATGGGTGT; MCP-1 forward CTTCTGGGCCTGCTGTTCA, reverse CCAGCCTACTCATTGGGATCA, TaqMan Probe CTCAGCCAGATGCAGTTAACGCCCC.

\section{Statistical analysis}

The data were initially analysed using Komogorov-Smirnov test to verify their symmetry. As all data had normal distribution, $t$ test and ANOVA were used to compare two and three independent groups respectively, with the level of significance set at $P<0.05$.

\section{Results}

Table 1 shows that TOH did not affect food intake and body weight. Since food intake was the same for both groups, TOH intake is expected to be higher in the $\mathrm{TOH}-$ supplemented compared with CT group. The higher levels of $\mathrm{TOH}$ in serum and liver in $\mathrm{TOH}$ group were confirmed by HPLC analysis (Table 1). The TOH supplementation had no effect on total cholesterol levels in serum (Table 1) or on its distribution among the different lipoprotein fractions (results not shown). Similar to the findings in serum, there were no differences in the hepatic concentrations of cholesterol (Table 1), suggesting that differences in the size of atherosclerotic lesions could not be due to differences in the levels of cholesterol in liver or blood.

Histological observation of the aorta before the supplementation with $\mathrm{TOH}$ (at 16 weeks of age) showed initial fatty streak lesions in animals fed on CT (results not shown). Quantitative histological analysis of an aortic lesion is shown in Fig. 1. Both the average of the largest lesion (Fig. 1(A)) and total lesion (Fig. 1(B)) areas was smaller at week 16 than at 22 in CT groups $(P=0.049$ and 0.029 respectively). However, no statistical increase in lesion area was detected after 6 weeks of TOH supplementation when $\mathrm{CT}$ at week 16 and $\mathrm{TOH}$ at week 22 were compared (Fig. 1(A and B)). The TOH supplementation was able to prevent the development of lesion area at week 22 when compared with the non-supplemented group at the same week $(P<0 \cdot 05)$. Besides the lesion size, CT animals showed more advanced lesions with intimal thickening, necrotic core and deposition of inflammatory and smooth muscle cells between the endothelium and foam cells when compared with the TOH group (Fig. 2).

Table 1. Final body weight, and serum cholesterol and $\alpha$-tocopherol levels in mice fed on control diet supplemented with $29.5 \mathrm{mg}$ or $588 \mathrm{mg} \alpha$-tocopherol $/ \mathrm{kg}$ diet $^{*}$

(Mean values with their standard errors)

\begin{tabular}{|c|c|c|c|c|c|c|}
\hline \multirow{2}{*}{$\begin{array}{l}\text { Diet... } \\
\text { Variables }\end{array}$} & \multicolumn{3}{|c|}{$\mathrm{CT}$} & \multicolumn{3}{|c|}{$\mathrm{TOH}$} \\
\hline & $n$ & Mean & SE & $n$ & Mean & SE \\
\hline Final body weight (g) & 15 & $19 \cdot 3$ & $2 \cdot 3$ & 17 & $18 \cdot 5$ & 0.6 \\
\hline Serum TOH $(\mathrm{mg} / \mathrm{l}) \dagger$ & 2 & 4.92 & 0.44 & 2 & $15 \cdot 51$ & 1.40 \\
\hline Liver TOH (ng/mg) & 5 & $5 \cdot 81$ & 1.58 & 5 & nd & nd \\
\hline \multicolumn{7}{|c|}{ Serum cholesterol $(\mathrm{mmol} / \mathrm{l})$} \\
\hline Week 16 & 15 & $6 \cdot 7$ & 0.7 & 17 & $6 \cdot 2$ & 0.5 \\
\hline Week 22 & 15 & $12 \cdot 4$ & $1 \cdot 0$ & 17 & $10 \cdot 6$ & $1 \cdot 17$ \\
\hline Liver cholesterol (mg/g) & 10 & $8 \cdot 4$ & 1.9 & 10 & $9 \cdot 5$ & 1.9 \\
\hline
\end{tabular}

CT, control; TOH, $\alpha$-tocopherol; nd, not detected.

*For details of diets and procedures, see p. 4.

t The values refer to the concentrations in two different pools of serum. 


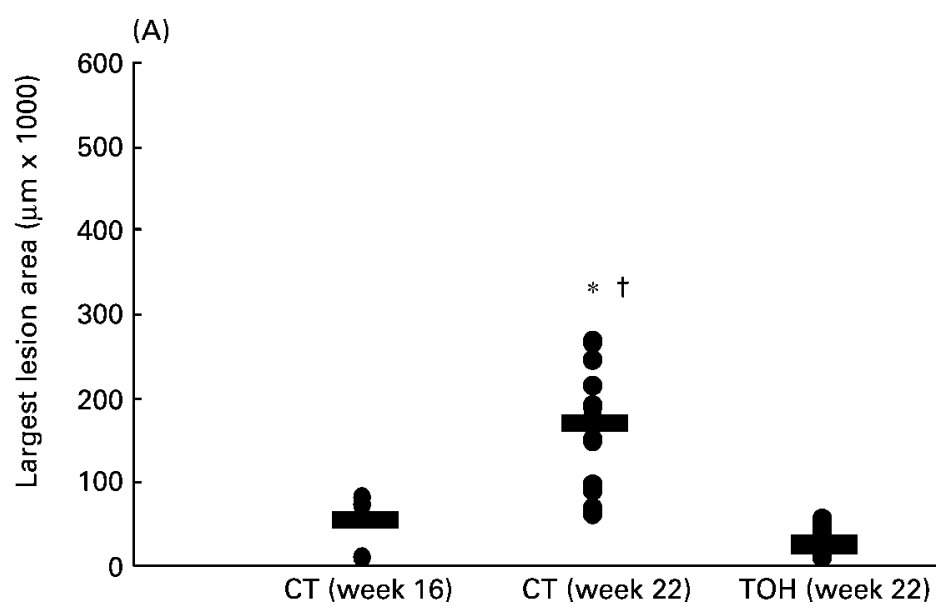

(B)

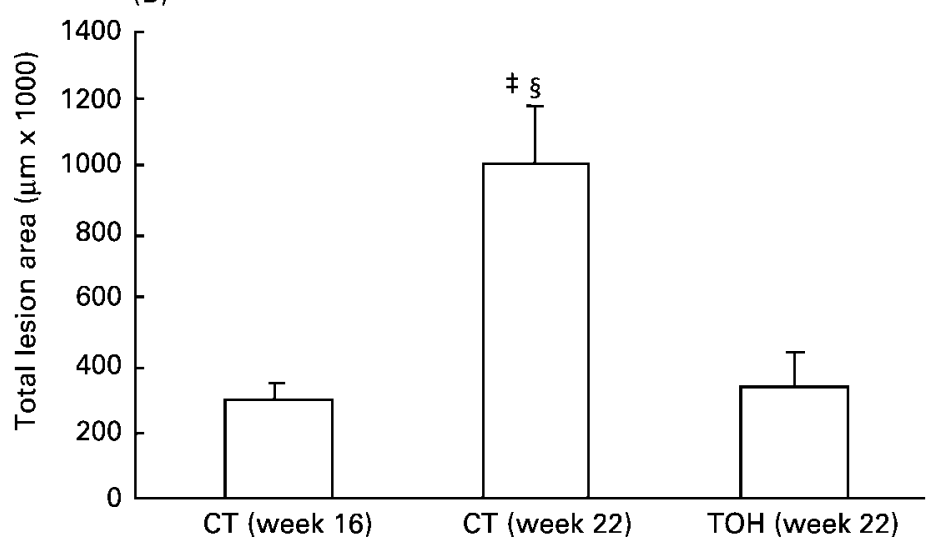

Fig. 1. Morphometrical evaluation of aortic lesions of apolipoprotein $E$ knockout mice fed on control (CT) diet or CT diet supplemented with $800 \mathrm{mg} \alpha$-tocopherol $(\mathrm{TOH}) / \mathrm{kg}$ diet. (A), the area of the largest sampled lesion of 16-week-old mice using CT diet (week 16) or after an additional 6 weeks (week 22) on CT or TOH-supplemented CT diet. Mean value was significantly different from that for TOH at week 22: ${ }^{\star} P=0.0001$. Mean value was significantly different from that for $C T$ group at week $16: \dagger P=0.049$. (B), the total analysed lesion area of 16-weekold apolipoprotein-E knockout mice using CT diet (week 16), after an additional 6 weeks fed CT (week 22) or CT diet with TOH supplementation (week 22). Values are means with their standard errors shown by vertical bars. Mean value was significantly different from that for CT at week 16: $\ddagger P=0.029$. Mean value was significantly different from that for $\mathrm{TOH}$ at week 22 : $\S P=0.0105$. For details of diets and procedures see p. 4.

When the expression of MCP-1 protein was evaluated (Fig. 3), mononuclear cells positive for MCP-1 were seen in the lesion area of the aorta in the CT group (Fig. 3(A)). Only sparse positive cells were observed in tissues of animals supplemented with $\mathrm{TOH}$ (Fig. 3(B)). Analysis of immunostained cells ((positive cells $(n) /$ total cells $(n)) \times 100)$ showed that the \% MCP-1-positive mononuclear cells was significantly greater in the $\mathrm{CT}$ group as compared with the $\mathrm{TOH}$ and wild-type (C57B1/6 mice) groups (Fig. 3(C)). To determine whether MCP-1 mRNA expression was also altered after TOH treatment, MCP-1 mRNA was assessed in the distal and proximal aorta by real-time quantitative PCR (Fig. 4). The results are in agreement to those seen after immunostaining of lesions in the aortic valve: there was a significant reduction in MCP-1 expression after TOH supplementation (Fig. 3(A)).

The results of real-time PCR showed that expression of MCP-1 in the aorta of the TOH group and wild-type group was similar. However, MCP-1 protein, as assessed by immunohistochemistry, was higher in $\mathrm{TOH}$ compared with the wild-type group. The reason for these apparently divergent results is that the analyses were done in different sites of the aorta: total RNA was extracted from the proximal and distal aorta and immunohistochemistry was performed at lesions in the aortic valve. Therefore, the differences between ApoE knockout (supplemented or not with $\mathrm{TOH}$ ) and wild-type animals will be more pronounced in the lesion area than in the total proximal and distal aorta, where the number of non-stimulated cells is higher than in the lesion area.

\section{Discussion}

Observational studies indicated that the consumption of vitamin $E$ reduces atherosclerosis progression (Rimm et al. 1993; Hodis et al. 1995; Azen et al. 1996). However, randomized controlled trials have had conflicting results regarding the effects of this vitamin on atherosclerosis (Stephens et al. 1996; GISSI-Prevenzione Investigators, 1999; Boaz et al. 2000; Salonen et al. 2000; The Heart Outcomes Prevention Evaluation Study Investigators, 2000; Brown et al. 2001; Collaborative Group of the Primary Prevention Group, 2001; Iuliano et al. 2001; Lonn et al. 2001; Hodis et al. 2002; Howard et al. 2002). 

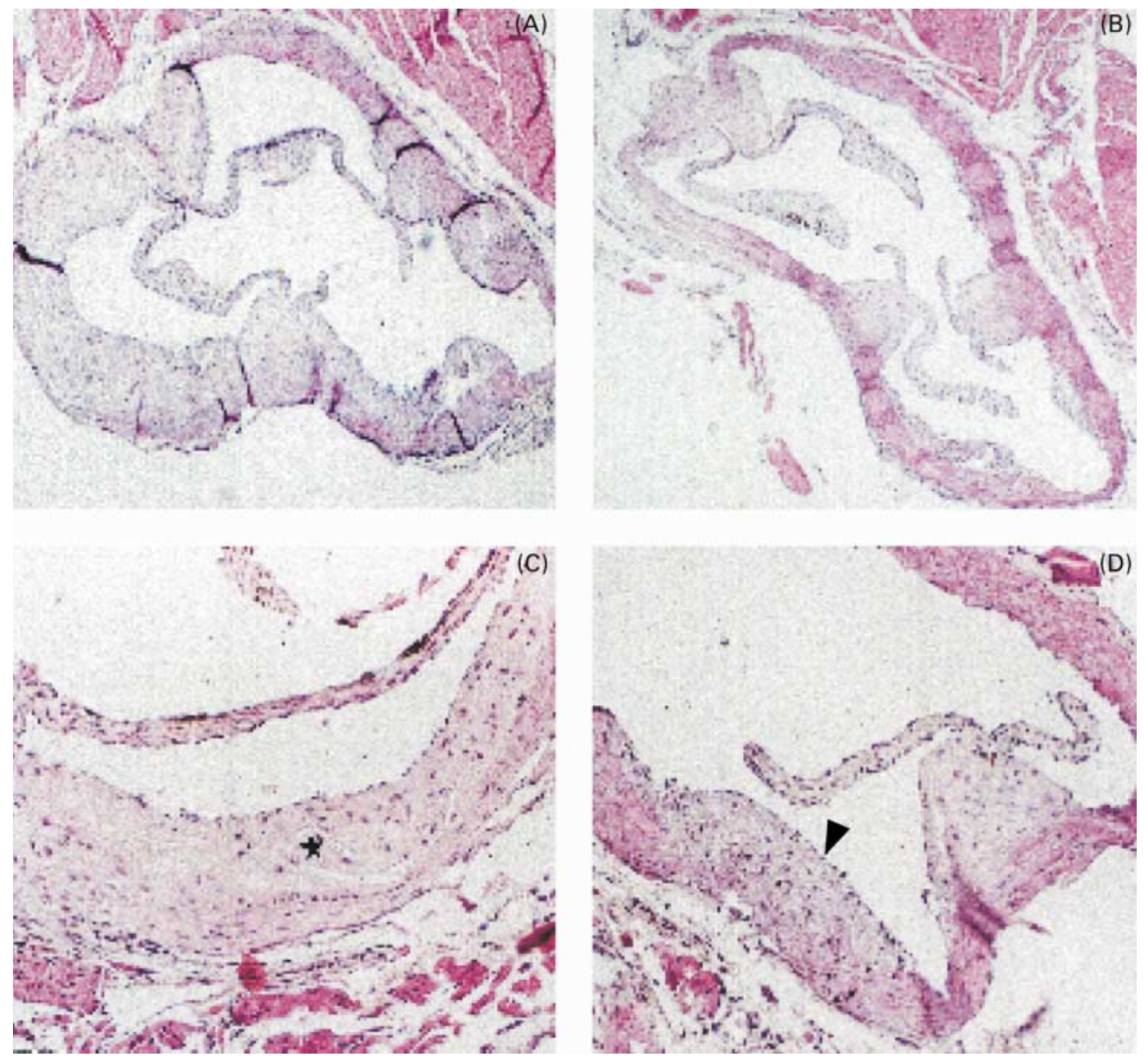

Fig. 2. Histopathological analysis of aorta of apolipoprotein $E$ knockout mice fed on control diet $(A$ and $C)$ or control diet supplemented with $800 \mathrm{mg} \alpha$-tocopherol $/ \mathrm{kg}$ diet (B and $D)$. (C), (D), details of slides showing a small proportion of the wall area thickened by necrotic degeneration $\left(^{*}\right)$ and thin fibrous cap $(\leftarrow)$. Original magnification: $(A)$ and $(B) \times 58$; $(C)$ and $(D) \times 256$. For details of diets and procedures, see p. 4.

Several recent comments and reviews have addressed this subject, but there is still no plausible explanation for these conflicting results (McCall \& Frei, 1999; Stocker, 1999; Chisolm \& Steinberg, 2000; Steinberg, 2000; Landmesser \& Harrison, 2001; Heinecke, 2001; Witztum \& Steinberg, 2001; Brown et al. 2002; Devaraj et al. 2002; Huang et al. 2002; Rilley \& Stouffer, 2002; Steinberg \& Witztum, 2002). Against this conflicting background, it is important to identify the components of atherosclerosis that can be modulated by tocopherols. Knowledge about the molecular mechanism of action of vitamin $\mathrm{E}$ will help to elucidate the situations where vitamin E supplementation could be advantageous. Our present study addressed this question and showed that, at least in the initial stages, TOH supplementation was able to impair atherosclerotic development through a mechanism that involved reduction of MCP-1 production.

Although atherosclerosis is a complex human disease, ApoE knockout mice develop lesions very similar to those found in human subjects and are, thus, a suitable model for studies of atherosclerosis (Virmani et al. 2000). According to Hayek et al. (1994), atherosclerosis in ApoE knockout animals is related to the increase of lipid peroxidation in plasma, especially of lipoproteins.
As in trials with human subjects, there are conflicting reports on the ability of $\mathrm{TOH}$ to protect against atherosclerosis (Phonpanichrasamee et al. 1990; Williams et al. 1992; Kayden \& Traber, 1993; Nakashima et al. 1994; Crawford et al. 1998; Munday et al. 1998; Parthasarathy et al. 1998; Asmis \& Jelk, 2000; Tsimikas et al. 2000; Peluzio et al. 2001; Upston et al. 2002). This divergence may be explained by differences in dietary composition, dose of vitamin administered and the degree of pre-existing lesions. We previously showed the effect of TOH $(400 \mathrm{mg} /$ $\mathrm{kg}$ atherogenic diet) in reducing aortic lesions in ApoE knockout mice supplemented from 4 to 10 weeks old, when fatty streaks are absent or very sparse (Peluzio et al. 2001). In the present study, the supplementation with $\mathrm{TOH}$ was also efficient when initiated after the establishment of the initial aortic lesion and maintained until intermediate stages, suggesting the protective effect of this vitamin during the establishment of fatty streaks.

Praticò et al. (1998) reported a lesion area 2.5-times smaller in the TOH-supplemented group $(2000 \mathrm{mg} / \mathrm{kg}$ diet) compared with $\mathrm{CT}$ group. We obtained the same reduction administrating lower doses of vitamin $\mathrm{E}$ for a shorter time. On the other hand, vitamin E deficiency caused by disruption of the TOH transfer protein gene 

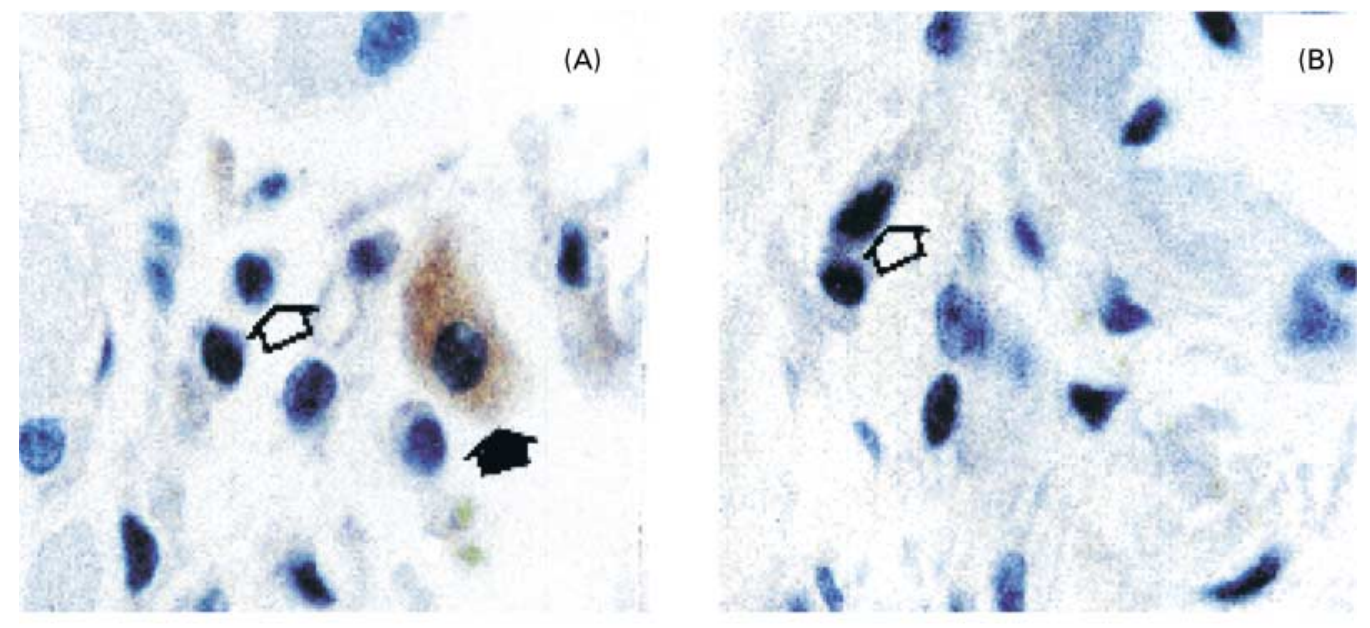

(C)

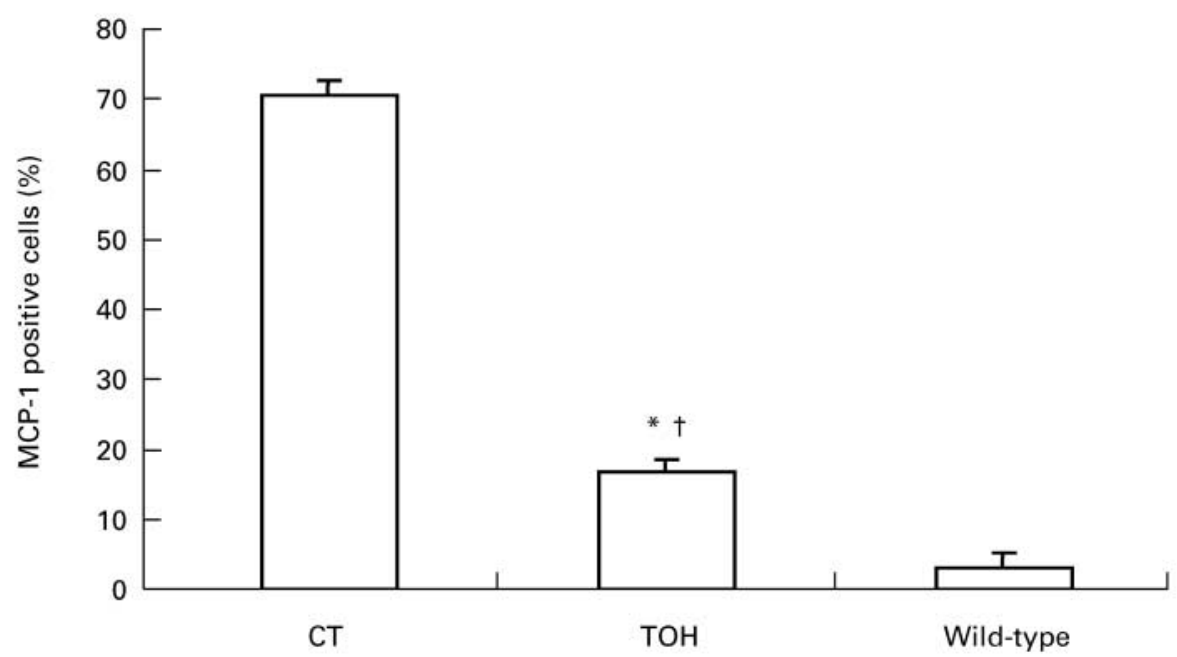

Fig. 3. The immunostained sections (A and B) of aortic lesions of apolipoprotein E knockout mice fed on control (CT) diet or CT diet supplemented with $800 \mathrm{mg} \alpha$-tocopherol $(\mathrm{TOH}) / \mathrm{kg}$ diet. (A), monocyte chemoattractant protein (MCP)- 1 has increased expression in aortic lesions mice fed on CT diet. (B), TOH-supplemented mice have little expression of MCP-1 protein by macrophages. $\rightarrow$, macrophages positive for MCP-1 protein; $\Rightarrow$, macrophages negative for MCP-1 protein. Original magnification $\times 990$. (C), quantitative analysis of immunostained tissue sections showing \% MCP-1 positive mononuclear cells. The \% MCP-1 positive cells was calculated by counting the average of total and the MCP-1 positive inflammatory cells observed in ten different slides per mouse (five $\times 40$ fields per slide). The percentage of positive cells was 70.5 for CT group, 16.7 for TOH-supplemented group and 3.2 for wild-type (C57BL/6) mice. Values are means for five mice per group with their standard errors shown by vertical bars. Mean value was significantly different from that of the CT group: ${ }^{*} P<0 \cdot 0001$. Mean value was significantly different from that of the wild-type group: $\dagger P<0.001$. For details of diets and procedures see p. 4 .

increased the severity of atherosclerotic lesion in ApoE knockout mice (Terasawa et al. 2000).

Studies using mice that overexpress MCP-1 have shown variable results with regard to monocyte infiltration (Phonpanichrasamee et al. 1990; Munday et al. 1998). In the same way, in ApoE knockout mice the additional deficiency of CCR2 gene, despite producing hypercholesterolaemia, reduced tissue macrophage and atherosclerosis formation (Boring et al. 1998). Thus, a causal relationship between accumulation and modification of LDL and monocyte recruitment to the arterial wall seems to exist in the initial stages of atherosclerotic lesion development (Frei, 1999).

Attraction and adhesion of immune cells to the vascular endothelium and subsequent transmigration are important steps in the initiation and development of the inflammatory process associated with atherosclerosis.
Oxidized lipoproteins may modulate the expression of adhesion molecules and stimulate monocyte recruitment and monocyte-endothelial interactions via chemokines such as MCP-1. Vitamin E could exert its protective effects against cardiovascular diseases by protecting LDL against oxidative modification, leading to decreased adhesion molecule and MCP-1 expression and foam cell formation (Djahansouzi et al. 2001). Alternatively, the vitamin could act directly on gene expression, reducing the expression of this chemokine.

Although there are some in vitro studies showing the influence of $\mathrm{TOH}$ supplementation on the production of MCP-1 (Wu et al. 1999), we provide in vivo evidence that the expression of MCP-1 is increased in aortic lesion in ApoE knockout animals and that TOH supplementation decreases its expression. 


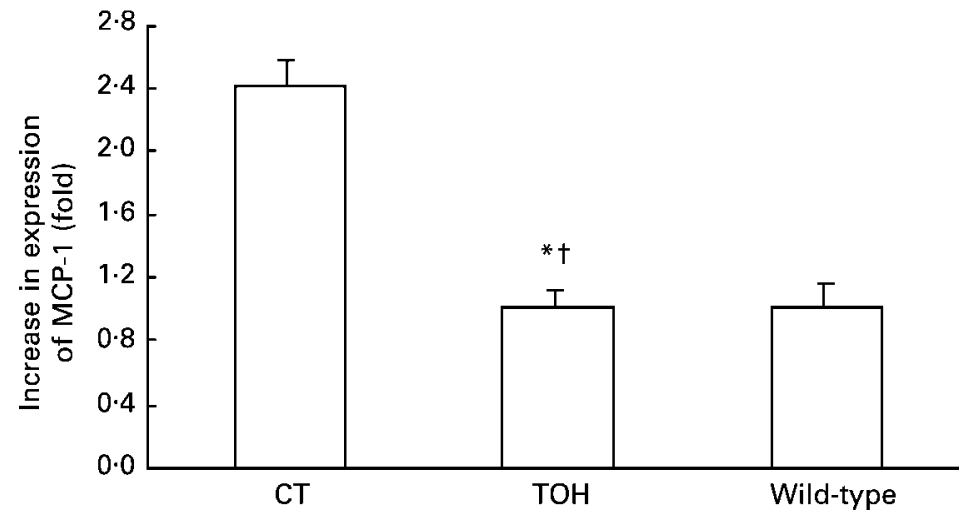

Fig. 4. Real-time quantitative polymerase chain reaction analyses: expression of the monocyte chemoattractant protein (MCP)-1 endogenous mRNA in aortic tissue of apolipoprotein E knockout mice receiving control (CT) diet, CT diet supplemented with $800 \mathrm{mg} \alpha$-tocopherol (TOH)/kg and wild-type (C57BL/6) mice. Values are means for five mice per group with their standard errors shown by vertical bars. For details of diets and procedures see p. 4. Mean value of $\mathrm{TOH}$ group was significantly different from that of the $\mathrm{CT}$ group: ${ }^{\star} P=0.0003$. Mean value of wild-type group was significantly different from that of the CT group: $† P<0.001$.

Our present results are in agreement with the hypothesis that one of the favourable effects of $\mathrm{TOH}$ is changing the expression of some important chemotactic molecules (as MCP-1). In this way, it can be hypothesized that vitamin E could be efficient in reducing fatty streak formation by reducing cell migration to the lesion site. In human trials, this positive action could be masked by other associated risk factors, making $\mathrm{TOH}$ supplementation ineffective in some of the published studies, mainly in secondary prevention.

In conclusion, the results obtained here are relevant to the study of atherosclerosis, as they correlate the effectiveness of vitamin $E$ supplementation with a mechanism that implicates macrophage-active chemokines in the genesis of the early phase of atherosclerosis.

\section{Acknowledgements}

The authors wish to thank: Dr Eloísa Saliba, Dr Marcelo Santoro and especially Mr Jamil Silvano de Oliveira and Ms Maria Lúcia G. S. Gonçalves for assistance with HPLC and fast protein liquid chromatography analysis; Dr Ricardo Gazzinelli for the real-time PCR assistance and critical review of the manuscript; Dr Leonides Rezende Junior and Katal (Belo Horizonte, Brazil) for donating cholesterol kits; Ms Maria Helena Alves de Oliveira and Ms Vania Aparecida da Silva for technical help. Our work was supported by Coordenação de Aperfeiçoamento de Pessoal de Ensino Superior (CAPES), Conselho Nacional de Desenvolvimento Científico e Tecnológico $(\mathrm{CNPq})$, Fundação de Amparo à Pesquisa do Estado de Minas Gerais (FAPEMIG) and Pro-reitoria de Pesquisa da Universidade Federal de Minas Gerais (PrPq-UFMG).

\section{References}

Aiello RJ, Bourassa P-AK, Lindsey S, et al. (1999) Monocyte chemoattractant protein-1 accelerates atherosclerosis in apolipoprotein E-deficient mice. Arterioscler Thromb Vasc Biol 19, $1518-1525$.
Allain CC, Poon LS, Chan CSG, Richmond W \& Fu PC (1974) Enzymatic determination of total serum cholesterol. Clin Chem 20, 470-475.

Asmis R \& Jelk J (2000) Vitamin E suplementation of human macrophages prevents neither foam cell formation nor increased susceptibility of foam cells to lysis by oxidized LDL. Arterioscler Thromb Vasc Biol 20, 2078-2086.

Azen SP, Qian D, Mack WJ, et al. (1996) Effect of supplementary antioxidant vitamin intake on carotid arterial wall intimamedia thickness in a controlled clinical trial of cholesterol lowering. Circulation 94, 2369-2372.

Boaz M, Smetana S, Weinstein T, et al. (2000) Secondary prevention with antioxidants of cardiovascular disease in endstage renal disease (SPACE): randomised placebo-controlled trial. Lancet 356, 1213-1218.

Boisvert WA, Black AS \& Curtiss LK (1999) Apo A1 reduces free cholesterol accumulation in atherosclerosis lesions of apo E-deficient mice transplanted with apo E-expressing macrophages. Arterioscler Thromb Vasc Biol 19, 525-530.

Boring L, Gosling J, Cleary M \& Charo IF (1998) Decreases lesion formation in CCR2- mice reveals a role for chemokines in the formatin of atherosclerosis. Nature 394, 894-897.

Brown BG, Cheung MC, Lee AC, Zhao XQ \& Chait A (2002) Antioxidant vitamins and lipid therapy: end of a long romance? Arterioscler Thromb Vasc Biol 22, 1535-1546.

Brown BG, Zhao XQ, Chait A, et al. (2001) Simvastatin and niacin, antioxidant vitamins, or the combination for the prevention of coronary disease. New Eng J Med 345, 1583-1592.

Chisolm GM \& Steinberg D (2000) The oxidative modification hypothesis of atherogenesis: an overview. Free Radic Biol Med 28, 1815-1826.

Collaborative Group of the Primary Prevention Project (2001) Low-dose aspirin and vitamin $\mathrm{E}$ in people at cardiovascular risk: a randomized trial in general practice. Lancet 357, 89-95.

Crawford RS, Kirk EA, Rosenfeld ME, LeBoeuf RC \& Chait A (1998) Dietary antioxidants inhibit development of fatty streak lesions in the LDL receptor-deficient mouse. Arterioscler Thromb Vasc Biol 18, 1506-1513.

Devaraj S, Harris A \& Jialal I (2002) Modulation of monocytemacrophage function with $\alpha$-tocopherol: implications for atherosclerosis. Nutr Rev 60, 8-13.

Djahansouzi S, Braesen JH, Koenig K, Beisiegel V \& Kontush A (2001) The effect of phamacological doses of different antioxidants on oxidation parameters and atherogenesis in hyperlipidaemic rabbits. Atherosclerosis 154, 387-398.

Fazio S, Babaev VR, Murray AB, et al. (1997) Increased 
atherosclerosis in mice reconstituted with apolipoprotein E null macrophages. Proc Natl Acad Sci USA 94, 4647-4652.

Folch J, Lees M \& Stanley S (1957) A simple method for the isolation and purification of total lipides from animal tissues. J Biol Chem 226, 497-509.

Frei B (1999) On the role of vitamin C and other antioxidants in atherogenesis and vascular dysfunction. Proc Soc Exp Biol Med 222, 196-204.

GISSI-Prevenzione Investigators (1999) Dietary supplementation with $n-3$ polyunsaturated fatty acids and vitamin $\mathrm{E}$ after myocardial infarction: results of the GISSI-Prevenzione trial. Lancet 354, 447-455.

Giulietti A, Overbergh L, Valckx D, Decallonne B, Bouillon R \& Mathieu C (2001) An overview of real-time quantitative PCR: Applications to quantify cytokine gene expression. Methods 25, 386-401.

Gu L, Okada Y, Clinton SK, et al. (1998) Absence of monocyte chemoattractant protein 1 reduces atherosclerosis in low density lipoprotein receptor-deficient mice. Mol Cell 2, 275-281.

Hayek T, Oiknine J, Brook JG \& Aviram M (1994) Increased plasma and lipoprotein lipid peroxidation in Apo-E deficient mice. Biochem Biophys Res Comm 3, 1567-1574.

Heinecke JW (2001) Is the emperor wearing clothes? Clinical trials of vitamin $\mathrm{E}$ and the LDL oxidation hypothesis. Arterioscler Thromb Vasc Biol 21, 1261-1264.

Hodis HN, Mack WJ \& LaBree L (2002) Alpha-tocopherol supplementation in healthy individuals reduces low-density lipoprotein oxidation but not atherosclerosis: the Vitamin Atherosclerosis Prevention Study (VEAPS). Circulation 106, $1453-1459$.

Hodis HN, Mack WJ, LaBree L, et al. (1995) Serial coronary angiographic evidence that antioxidant vitamin intake reduces progression of coronary artery atherosclerosis. JAMA 273, 1849-1854.

Howard HN, Wendy MJ, LaBree L, et al. (2002) Alpha-tocopherol supplementation in healthy individuals reduces low-density lipoprotein oxidation but not atherosclerosis: The Vitamin E Atherosclerosis Prevention Study (VEAPS). Circulation 106, $1453-1459$.

Huang HY, Appel LJ, Croft KD, Miller ER 3rd, Mori TA \& Puddey IB (2002) Effects of vitamin $C$ and vitamin $E$ on in vivo lipid peroxidation: results of a randomized controlled trial. Am J Clin Nutr 76, 549-555.

Iuliano L, Micheletta F, Maranghi M, Frati G, Diczfalusy U \& Violi $F$ (2001) Bioavailability of vitamin $E$ as function of food intake in healthy subjects: effects on plasma peroxide-scavenging activity and cholesterol-oxidation products. Arterioscler Thromb Vasc Biol 21, e34-e37.

Kayden HJ \& Traber MG (1993) Absorption, lipoprotein transport and regulation of plasma concentrations of vitamin $\mathrm{E}$ in humans. J Lipid Res 34, 343-358.

Landmesser U \& Harrison DG (2001) Oxidant stress as a marker for cardiovascular events: Ox marks or spot. Circulation 104, $2638-2640$.

Libby P, Geng YJ, Masanori A, et al. (1996) Macrophages and atherosclerotic plaque stability. Curr Opin Lipidol 7, 330-335.

Lonn E, Yusuf S, Dzavik V, et al. (2001) Effects of ramipril and vitamin $\mathrm{E}$ on atherosclerosis: the study to evaluate carotid ultrasound changes in patients treated with ramipril and vitamin E (SECURE). Circulation 103, 919-925.

McCall MR \& Frei B (1999) Can antioxidant vitamins materially reduce oxidative damage in humans? Free Radic Biol Med 26, 1034-1053.

Munday JS, Thompson KG, James KAC \& Manktelow BW (1998) Dietary antioxidants do not reduce fatty streak formation in the C57BL/6 mouse atherosclerosis model. Arterioscler Thromb Vasc Biol 18, 114-119.
Nakashima Y, Plump AS, Raines EW, Breslow JL \& Ross R (1994) Apo E-deficient mice develop lesions of all phases of atherosclerosis throughout the arterial tree. Arterioscler Thromb Vasc Biol 14, 133-140.

Nelken NA, Coughlin SR, Gordon D \& Wilcox JN (1991) Monocyte chemoattractant protein-1 in human atheromatous plaques. $J$ Clin Invest 88, 1121-1127.

Overbergh L, Valckx D, Waer M \& Mathieu C (1998) Quantification of murine citokine mRNAs using real-time quantitative reverse transcriptase PCR. Cytokine 11, 305-312.

Packer L (1991) Protective role of vitamin E in biological systems. Am J Clin Nutr 53, 1050S-1055S.

Paigen B, Morrow A, Holmes PA, Mitchell D \& Williams A (1987) Quantitative assessment of atherosclerosis lesions in mice. Atherosclerosis 68, 231-240.

Parthasarathy S, Santanam N \& Augé N (1998) Oxidized lowdensity lipoprotein, a two-faced Janus in coronary artery disease? Biochem Pharmacol 56, 279-284.

Peluzio MCG, Homen APP, Cesar GC, et al. (2001) Influences of $\alpha$-tocopherol on cholesterol metabolism and fatty streak development in apo E deficient atherogenic diet. Braz J Med Biol Res 35, 161-173.

Phonpanichrasamee C, Komaratat P \& Wilairat P (1990) Hypocholesterolemic effect of vitamin $\mathrm{E}$ on cholesterol-fed rabbit. Int J Vitam Nutr Res 60, 240-244.

Praticò D, Tangirala RK, Rader DJ, Rokach J \& FitzGerald GA (1998) Vitamin E supresses isoprostane generation in vivo and reduces atherosclerosis in Apo-E deficient mice. Nat Med 10, 1189-1192.

Reddick RL, Zhang SH \& Maeda N (1994) Atherosclerosis in mice lacking apo E. Evaluation of lesional development and progression. Arterioscler Thromb Vasc Biol 14, 141-147.

Reeves PG, Nielsen FH \& Fahey GC Jr (1993) AIN-93 purified diets for laboratory rodents: final report of the American Institute of Nutrition ad hoc writing committee on the reformulation of the AIN-76A rodent diet. J Nutr 123, 1936-1951.

Ricciarelli R, Zing JM \& Azzi A (2002) The 80th anniversary of vitamin E: beyond its antioxidant properties. Biol Chem 383, $57-65$.

Rilley JS \& Stouffer GA (2002) The antioxidant vitamins and coronary heart disease: Part I. Basic science background and clinical observational studies. Am J Med Sci 324, 314-320.

Rimm EB, Stampfer MJ, Ascherio A, Giovannucci E, Colditz GA \& Willett WC (1993) Vitamin E consumption and the risk of coronary heart disease in men. New Eng J Med 328, 1450-1456.

Salonen JT, Nyyssonen K, Salonen R, et al. (2000) Antioxidant supplementation in atherosclerosis prevention (ASAP) study: a randomized trial of the effect of vitamins $\mathrm{E}$ and $\mathrm{C}$ on 3-year progression of carotid atherosclerosis. J Int Med 248, 377-386.

Sies H, Stahl W \& Sundquist AR (1992) Antioxidant functions of vitamins. Vitamins $\mathrm{E}$ and $\mathrm{C}$, beta-carotene and other carotenoids. Ann NY Acad Sci 669, 7-20.

Steinberg D (2000) Is there a potential therapeutic role for vitamin $\mathrm{E}$ or other antioxidants in atherosclerosis? Curr Opin Lipidol 11, 603-607.

Steinberg D (1992) Antioxidants in prevention of human atherosclerosis. Summary of the proceedings of a National Heart, Lung and Blood Institute Workshop, September 5-6, 1991, Bethesda, Maryland. Circulation 85, 2337-2344.

Steinberg D \& Witztum JL (2002) Is the oxidative modification hypothesis relevant to human atherosclerosis?, Do the antioxidant trials conducted to date refute the hypothesis? Circulation 105, 2107-2111.

Stephens NG, Parsons A, Schofield PM, Kelly F, Cheeseman K \& Mitchinson MJ (1996) Randomized controlled trial of vitamin $\mathrm{E}$ in patients with coronary disease: Cambridge Heart Antioxidant Study (CHAOS). Lancet 347, 781-786. 
Stocker R (1999) Dietary and pharmacological antioxidants in atherosclerosis. Curr Opin Lipidol 10, 589-597.

Takeya M, Yoshimura T, Leonharf EJ \& Takahashi K (1993) Detection of monocyte chemoattractant protein-1 in human atherosclerotic lesions by an anti-monocyte chemoattractant protein-1antibody. Hum Pathol 24, 534-539.

Tangirala RK, Rubin EM \& Palinski W (1995) Quantification of atherosclerosis in murine models: correlation between lesions in the aortic origin and in the entire aorta, and differences in the extent of lesions between sexes in LDL receptor-deficient and apolipoprotein-E deficient mice. $J$ Lipid Res 36, $2320-2328$.

Terasawa Y, Ladha Z, Leonard SW, et al. (2000) Increased atherosclerosis in hyperlipidemic mice deficient in $\alpha$-tocopherol transfer protein and vitamin E. Proc Natl Acad Sci USA 97, $13830-13834$.

The Heart Outcomes Prevention Evaluation Study Investigators (2000) Vitamin E supplementation and cardiovascular events in high-risk patients. New Eng J Med 342, 154-160.

Tsimikas S, Shortal BP, Witztum JL \& Palinski W (2000) In vivo uptake of radiolabeled MDA, an oxidation-specific monoclonal antibody, provides an accurate measure of atherosclerotic lesions to their regression. Arterioscler Thromb Vasc Biol 20 , 689-697.
Ueda T \& Igarashi O (1990) Determination of vitamin E in biological specimens and foods by HPLC-pretreatment of samples and extraction of tocopherols. J Micronutr Anal 7, 79-96.

Upston JM, Terentis AC, Morris K, Keaney JF Jr \& Stocker R (2002) Oxidized lipid accumulates in the presence of alphatocopherol in atherosclerosis. Biochem J 363, 753-760.

Virmani R, Kolodgie FD, Burke AP, Farb A \& Schwartz SM (2000) Lessons from sudden coronary death. A comprehensive morphological classification scheme for atherosclerotic lesions. Arterioscler Thromb Vasc Biol 20, 1262-1275.

Wefers H \& Sies H (1988) The protection by ascorbate and glutathione against microsomal lipid peroxidation is dependent on vitamin E. FEBS Lett 174, 353-357.

Williams RJ, Motteram JM, Sharp CH \& Gallagher PJ (1992) Dietary vitamin $\mathrm{E}$ and the attenuation of early lesion development in modified Watanabe rabbits. Atherosclerosis 94, 153-159.

Witztum JL \& Steinberg D (2001) The oxidative modification hypothesis of atherosclerosis: does it hold for humans? Trends Cardiovasc Med 11, 93-102.

Wu D, Koga T, Martin KR \& Meydani M (1999) Effect of vitamin E on human aortic endothelial cell production of chemokines and adhesion to monocytes. Atherosclerosis 147, 297-307. 